\title{
Penggunaan Blog dan Pembelajaran Kooperatif Tipe Numbered Head Together untuk Meningkatkan Pemahaman Konsep Tentang Usaha Mempertahankan Kemerdekaan Indonesia
}

\author{
N. Dewi Ratnaningsih ${ }^{1}$, Jamilah $^{2}$, Endang Dimyati ${ }^{3}$ \\ 1,2,3 Magister Teknologi Pendidikan, Sekolah Pascasarjana Institut Pendidikan Indonesia, Garut, \\ ratnengsih@institutpendidikan.ac.id
}

\begin{abstract}
Abstrak
Penggunaan blog mobile dan pembelajaran kooperatif tipe Numbered Head Together merupakan penelitian yang dilakukan untuk meningkatkan pemahaman konsep peserta didik tentang usaha mempertahankan kemerdekaan Indonesia. Penelitian dilakukan pada pembelajaran sejarah di SMK Darussalam Tarogong Kaler Garut kelas X. Metode penelitian yang digunakan adalah metode eksperimen dengan bentuk eksperimen semu. Bentuk desain eksperimen yang digunakan adalah pretest-posttest control group design dengan instrumen berupa tes dan non tes (angket). Dari hasil penelitian yang dilakukan, dapat disimpulkan bahwa Penggunaan blog mobile dan pembelajaran kooperatif tipe Numbered Head Together dapat meningkatkan pemahaman konsep peserta didik tentang usaha mempertahankan kemerdekaan Indonesia. Hal ini dapat dilihat dari peningkatan rata-rata nilai peserta didik dari 22 menjadi 46 dengan rata-rata n-gain 0,29 termasuk kategori rendah. Dari 25 orang peserta didik pada kelas eksperimen, sebanyak $4 \%$ peserta didik yang tuntas belajar dan $96 \%$ peserta didik belum tuntas belajar.
\end{abstract}

Kata Kunci: Blog, Numbered Head Together, Pembelajaran Kooperatif, Pemahaman Konsep

\begin{abstract}
The use of mobile blogs and cooperative learning with the Numbered Head Together type is research conducted to improve students' understanding of the concept of efforts to maintain Indonesian independence. The study was conducted on history learning at SMK Darussalam Tarogong Kaler Garut class X. The research method used was an experimental method with a quasi-experimental form. The form of experimental design used was a pretest-posttest control group design with instruments in the form of tests and non-tests (questionnaire). From the results of the research conducted, it can be concluded that the use of mobile blogs and cooperative learning with the Numbered Head Together type can improve students' understanding of the concept of efforts to maintain Indonesian independence. This can be seen from the increase in the average value of students from 22 to 46 with an average of $n$-gain of 0.29, including the low category. Of the 25 students in the experimental class, as many as $4 \%$ of students who have finished learning and $96 \%$ of students have not yet finished learning.
\end{abstract}

Keywords: Blog, Numbered Head Together, Cooperative Learning, Concept Understanding 


\section{PENDAHULUAN}

Pemahaman konsep merupakan bagian dari hasil dalam komponen pembelajaran. Pemahaman konsep dapat diperoleh dari pengalaman dan proses belajar. Seseorang dikatakan memahami konsep apabila orang tersebut mengerti benar konsep yang dipelajarinya. Pemahaman bukan hanya mengetahui yang sifatnya mengingat saja, tetapi mampu mengungkapkan kembali dalam bentuk lain atau dengan kata-kata sendiri sesuai dengan pengetahuan yang dimilikinya sehingga mudah dimengerti makna dari bahan yang dipelajari tanpa mengubah arti yang ada di dalamnya.

Terdapat dua cara untuk memperoleh konsep-konsep yaitu melalui pembentukan konsep dan asimilasi konsep. Pembentukan konsep merupakan proses induktif. Di dalam proses induktif peserta didik dilibatkan belajar penemuan. Sementara perolehan konsep melalui asimilasi erat kaitannya dengan proses deduktif.

Penggunaan blog mobile dan pembelajaran kooperatif tipe Numbered Head Together dalam pembelajaran sejarah merupakan salah satu cara yang dapat dilakukan untuk dapat meningkatkan pemahaman konsep peserta didik. Selain dapat membantu peserta didik dalam memahami konsep dengan mudah melalui bentuk pengalaman belajar yang konkret, juga dapat mengembangkan sikap social peserta didik.

Penggunaan media blog dan model pembelajaran kooperatif tipe Numbered Head Together dengan tujuan meningkatkan pemahaman konsep peserta didik tentang materi sejarah, tidak terlepas dari teori dan hasil penelitian orang lain yang menunjukkan keberhasilan. Diantaranya yaitu hasil penelitian dari Daud dkk (2011: 47) yang menunjukkan bahwa Penerapan model pembelajaran kooperatif tipe Numbered Head Together (NHT) dapat meningkatkan aktivitas belajar peserta didik. Hasil penelitian Abdillah dan Daud (2017) yang menunjukkan bahwa penerapan media pembelajaran blog dengan pendekatan scientific approach dapat meningkatkan prestasi belajar peserta didik yang ditunjukkan dengan perilaku yang lebih aktif dan fokus dalam mendengarkan materi, memecahkan masalah, bertanya, berdiskusi, mengeluarkan pendapat, dan membuat laporan. Peserta didik lebih bertanggung jawab dalam penguasaan materi dan diskusi kelompok.

Adapun teori-teori yang melandasi fokus masalah atau variabel yang akan diteliti adalah sebagai berikut. Edgar Dale (Abdulhak dan Darmawan, 2013: 113) dengan teori cone of experience menyatakan bahwa 'Simbol dan gagasan yang abstrak dapat lebih mudah dipahami dan diserap manakala diberikan dalam bentuk pengalaman yang konkret'. Pemikiran Edgar Dale tentang kerucut pengalaman (Cone of Experience) menunjukkan bahwa semakin konkrit pembelajaran yang dilakukan oleh seseorang, maka hasil belajarnya juga akan semakin optimal.

Vygotsky (Suprijono, 2016: 74) melalui Teori konstruktivisvisme sosial menekankan bahwa pengetahuan dibangun dan dikonstruksi secara 
mutual dimana peserta didik berada dalam konteks sosiohistoris. Keterlibatan dengan orang lain membuka kesempatan bagi mereka mengevaluasi dan memperbaiki pemahaman. Dengan cara ini, pengalaman dalam konteks sosial memberikan mekanisme penting untuk perkembangan pemikiran peserta didik.

\section{KAJIAN PUSTAKA Media Pembelajaran}

Media pengajaran atau media pembelajaran merupakan alat bantu mengajar yang ada dalam komponen metodologi pengajaran sebagai salah satu lingkungan belajar yang diatur oleh guru sebagai alat bantu agar bahan pengajaran sampai pada peserta didik sehingga peserta didik dapat menguasai tujuan pembelajaran. Media pengajaran terdiri dari beberapa jenis, yang pertama yaitu media grafis atau media dua dimensi seperti gambar, foto, grafik, bagan atau diagram, poster, kartun, komik dan lain-lain. Kedua, media tiga dimensi yaitu dalam bentuk model. Ketiga, media proyeksi seperti slide, film strips, film, penggunaan OHP, dan lain-lain. Keempat, penggunaan lingkungan sebagai media pengajaran.

Media pengajaran memiliki manfaat dan peran yang sangat penting dalam mencapai tujuan pembelajaran. Pemilihan media pengajaran harus disesuai dengan tujuan, karakteristik peserta didik, waktu yang tersedia dan isi bahan pengajaran. Sudjana dkk (2017: 4) mengemukakan kriteria dalam memilih media pengajaran, diantaranya:

1. Ketepatannya dengan tujuan pengajaran,
2. Dukungan terhadap isi bahan pelajaran,

3. Kemudahan dalam memperoleh media,

4. Keterampilan guru dalam menggunakannya,

5. Tersedia waktu untuk menggunakannya

6. Sesuai dengan taraf berpikir peserta didik.

Berdasarkan kriteria di atas, dapat diketahui bahwa tidak semua media pembelajaran tepat digunakan untuk membantu guru dalam menjelaskan bahan pengajaran. Penggunaan media yang kurang tepat dapat mempersulit guru menjalankan tugasnya. Oleh karena itu, media pembelajaran bukan merupakan suatu keharusan melainkan sebagai pelengkap jika dianggap perlu untuk mempertinggi kualitas belajar dan mengajar.

Dari penjelasan di atas, dapat diketahui bahwa media pengajaran ini memiliki peran yang sangat penting dalam proses pembelajaran, seperti yang dikemukakan oleh Maswan dan Muslimin (2017:123), yaitu:

Beberapa fungsi pokok atau peran alat peraga dalam proses belajar mengajar, antara lain adalah:
a. Sebagai alat bantu mewujudkan situasi pembelajaran yang efektif dan efisien.
b. Sebagai sarana untuk menumbuhkan dan mengembangkan situasi belajar mengajar lebih menarik dan dinamis.


c. Sebagai bagian integral dalam bentuk sarana untuk memperjelas isi materi pelajaran agar tujuan yang diinginkan tercapai.

d. Sebagai penguat daya tarik atau perhatian peserta didik untuk menangkap pesanpesan pembelajaran yang ditunjukkan dalam bentuk yang nyata.

e. Sebagai alat untuk memotivasi peserta didik dalam mempercepat penangkapan konsep dalam proses pembelajaran.

f. Sebagai sarana untuk membantu peserta didik dalam penerimaan dan daya ingat yang lebih lama mengenai materi yang diterimanya.

Dari penjelasan di atas, dapat diketahui bahwa peran atau fungsi dari media pengajaran ini sangat penting dalam membantu guru menjelaskan bahan pengajaran. Media pengajaran sebagai salah satu komponen dalam metode mengajar merupakan salah satu upaya untuk meningkatkan proses interaksi antara guru dan peserta didik serta interaksi antara peserta didik dengan lingkungan belajarnya. Fungsi utama media pengajaran adalah sebagai alat bantu mengajar, yakni menunjang penggunaan metode mengajar untuk memudahkan peserta didik dalam memahami apa yang disampaikan oleh guru.

Pada penelitian ini, media yang digunakan berfungsi sebagai alat bantu dalam mewujudkan situasi pembelajaran yang efektif dan efisien sehingga dapat menumbuhkan dan mengembangkan situasi belajar yang menarik dan dinamis. Dengan demikian, maka peserta didik diharapkan dapat termotivasi dan terbantu dalam penerimaan materi sehingga penangkapan konsep materi pembelajaran lebih cepat dan daya ingat terhadap materi pembelajaran juga dapat bertahan lama.

\section{Blog}

Blog atau biasa disebut dengan web log merupakan situs yang terdiri dari kumpulan entri atau posting yang muncul dalam urutan tanggal dari yang terlama menuju terbaru, dengan kata lain konten terbaru selalu ada di urutan teratas, mirip dengan jurnal harian. Blog biasanya memiliki fitur-fitur seperti komentar dan link untuk meningkatkan interaktivitas dengan pengguna. Blog dapat dibuat dengan perangkat lunak seperti wordpress, tumblr, blogspot, dan lain-lain.

Blog merupakan hasil evolusi dari dunia web mulai dari tampilan yang sederhana sampai dengan tersedianya layanan-layanan lain yang memudahkan orang membuat website dan mengupdatenya secara kontinyu. Media Blog pertama kali dipopulerkan oleh Blogger.com yang dimiliki oleh PyraLab pada tahun 2002 (Kristiyanti, 2011: 36).

Blog mempunyai fungsi yang sangat beragam, dari sebuah catatan harian, media publikasi dalam sebuah kampanye politik, sampai dengan program-program media dan perusahaan-perusahaan. Sebagian blog dipelihara oleh penulis tunggal sementara sebagian lainnya oleh beberapa penulis. Terdapat weblog yang bersifat interaktif dengan para 
pengunjungnya, namun ada juga weblog yang bersifat non-interaktif. Manfaat blog bagi dunia pendidikan menurut Sartono (2016: 124) yaitu sebagai berikut:

- Sebagai rumah belajar dan berbagi guru,

- Meringankan tugas dan beban guru dalam mengajar,

- Meningkatkan minat belajar peserta didik,

- Dapat diakses oleh siapapun di belahan dunia,

- Media silaturahmi.

Pengertian Blog dalam penelitian ini adalah jenis situs web pendidikan yang merupakan kumpulan entri atau posting tentang materi sejarah Indonesia yang dikembangkan dan dikelola oleh guru dengan menggunakan perangkat lunak (Software) online serta dapat diakses oleh semua pengguna internet termasuk peserta didik sesuai dengan topik dan tujuan pengguna blog tersebut yaitu sebagai media sekaligus sebagai sumber belajar dalam pembelajaran sejarah.

\section{Model pembelajaran}

Model pembelajaran

merupakan segala sesuatu yang telah dirancang sebelumnya oleh guru untuk dapat mencapai tujuan pembelajaran seperti yang diharapkan. Model pembelajaran merupakan kerangka konseptual yang melukiskan prosedur yang sistematis dan terencana dalam mengorganisasikan proses pembelajaran peserta didik sehingga tujuan pembelajaran dapat dicapai secara efektif. Model pembelajaran juga dapat dipahami sebagai blueprint guru dalam mempersiapkan dan melaksanakan proses pembelajaran. Menurut Joyce \& Weil (Rusman, 2016: 132)

Model pembelajaran merupakan suatu rencana atau pola yang dapat digunakan untuk membentuk kurikulum (rencana pembelajaran jangka panjang), merancang bahan pembelajaran, dan membimbing pembelajaran di kelas atau yang lain.

Model pembelajaran dapat dijadikan pola pilihan dalam rangka mencapai tujuan Pendidikan. Untuk mencapai tujuan pendidikan, tidak semua model pembelajaran cocok dengan semua mata pelajaran. Setiap mata pelajaran memiliki beberapa materi dengan tingkat keluasan dan kedalaman yang berbeda-beda. Terdapat beberapa kriteria dalam memilih model pembelajaran sehingga pembelajaran efektif dan efisien. Berikut ini dasar-dasar pertimbangan dalam memilih model pembelajaran menurut Priansa (2017: 188) yaitu:

Dalam memilih model pembelajaran yang akan digunakan, seorang guru harus mempertimbangkan beberapa hal seperti hasil (outcome) yang diharapkan seperti apa, isi/materi (content) apa yang harus dipahami, dan bagaimana proses pembelajaran yang harus dilakukan.

\section{Pertimbangan-pertimbangan}

mengenai pemilihan model pembelajaran untuk mencapai tujuan pendidikan, ditunjukkan pada gambar berikut ini. 


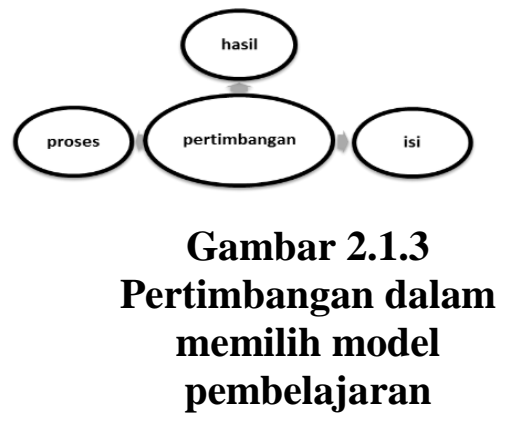

Ciri-ciri model pembelajaran menurut Rusman (2016: 132), yaitu sebagai berikut:

- Berdasarkan teori Pendidikan dan teori belajar dari para ahli tertentu.

- Mempunyai misi atau tujuan Pendidikan tertentu.

- Dapat dijadikan pedoman untuk perbaikan kegiatan belajar mengajar di kelas.

- Memiliki bagian-bagian model yang dinamakan: urutan langkahlangkah pembelajaran (syntax), adanya prinsip-prinsip reaksi, system sosial dan system pendukung.

- Memiliki dampak sebagai akibat terapan model pembelajaran.

- Membuat persiapan mengajar (desain instruksional) dengan pedoman model pembelajaran yang dipilihnya.

Pengertian model pembelajaran di dalam penelitian ini yaitu model pembelajaran adalah suatu kerangka konseptual yang disusun secara sistematis dalam merancang bahan pembelajaran sehingga tujuan dapat tercapai secara efektif. Akan tetapi, tidak semua pokok bahasan (materi) sesuai dengan satu model pembelajaran saja, melainkan harus dipilih model pembelajaran yang sesuai dengan materi pelajaran, tingkat perkembangan kognitif peserta didik, dan sarana atau fasilitas yang tersedia.

Model Pembelajaran Kooperatif Menurut Suprijono (2016: 47)

"Model Pembelajaran Kooperatif (Cooperative learning) merupakan suatu cara pendekatan atau serangkaian strategi yang khusus dirancang untuk memberi dorongan kepada peserta didik agar bekerja sama selama proses pembelajaran". Pembelajaran Kooperatif merupakan suatu model pembelajaran yang dilakukan secara tim untuk mencapai tujuan Bersama. Pembelajaran Kooperatif dikembangkan berdasarkan teori belajar kooperatif konstruktivis dari Vygotsky yang menekankan pada hakikat sosiokultural. Model pembelajaran kooperatif sangat berbeda dengan model pembelajaran langsung. Disamping untuk mencapai hasil belajar kompetensi akademik, model pembelajaran kooperatif juga dikembangkan untuk mencapai hasil belajar kompetensi sosial peserta didik.

Menurut Roger dan Davis Johnson (Rusman, 2016: 212), terdapat lima unsur dasar dalam pembelajaran Kooperatif, yaitu sebagai berikut:

1. Prinsip ketergantungan positif;

2. Tanggung jawab perseorangan;

3. Interaksi tatap muka;

4. Partisipasi dan komunikasi;

5. Evaluasi proses kelompok.

Kelima unsur pembelajaran kooperatif seperti yang telah dipaparkan di atas, selain dapat membuat peserta didik belajar secara aktif, juga dapat mengembangkan 
keterampilan sosialnya. Dengan penggunaan model pembelajaran kooperatif, ketergantungan postif antara peserta didik yang satu dengan peserta didik yang lainnya dapat terwujud. Mereka berkomunikasi untuk dapat memecahkan msalah bersama-sama. Selain itu, masingmasing peserta didik belajar untuk dapat melaksanakan tanggung jawabnya secara individu. Sehingga mereka mampu untuk berpartisipasi dalam kelompok.

Terdapat beberapa tipe atau metode pembelajaran Kooperatif yang dapat digunakan untuk membantu guru dalam merencanakan proses pembelajaran sehingga tercipta pembelajaran yang efektif dan efisien. Menurut Priansa (2017: 299) beberapa tipe atau metode pembelajaran kooperatif, diantaranya yaitu:

Contextual Teaching and Learning (CTL); problem based learning (PBL); teamsgames tournament (TGT); student teams achievement (STAD); Numbered Head Together (NHT); JIGSAW; Think Pairs Share (TPS); Group Invertigation (GI); cooperative, integrated, reading and composition (CIRC); talking stick; make a match.

Menurut Slavin (2016: 10), terdapat tiga konsep penting bagi semua metode Cooperative Learning yaitu "penghargaan bagi tim, tanggung jawab individual, dan kesempatan sukses yang sama".

Pengertian Pembelajaran kooperatif di dalam penelitian ini merupakan pembelajaran yang dilakukan oleh peserta didik dalam kelompok- kelompok kecil secara kolaboratif yang anggotanya terdiri dari empat sampai enam orang dengan struktur kelompok yang bersifat heterogen dan dirancang khusus memberi dorongan kepada peserta didik untuk bekerja sama selama proses pembelajaran supaya tujuan pembelajaran yang telah dirumuskan dapat tercapai.

\section{Numbered Head Together}

Numbered Head Together (NHT) menurut Suprijono (2016) merupakan "salah satu metode pembelajaran Kooperatif yang pembelajarannya dilakukan secara berkelompok dan diawali dengan Numbering". Tiap orang di dalam kelompok diberi nomor yang berbedabeda mulai dari nomor satu sampai seterusnya sesuai dengan jumlah anggota kelompok berdasarkan jumlah konsep yang dipelajari. Tiap kelompok bertugas untuk menjawab pertanyaan yang diberikan oleh guru dengan cara berdiskusi atau menyatukan kepalanya (heads together).

Numbered Head Together (NHT) merupakan varian dari diskusi kelompok dengan tujuan memberi kesempatan kepada peserta didik untuk saling berbagi gagasan dan mempertimbangkan jawaban yang paling tepat. Selain untuk meningkatkan kerja sama peserta didik, Number Head Together juga bisa diterapkan pada semua mata pelajaran dan tingkatan kelas. Model pembelajaran Numbered Head Together ini cocok untuk memastikan akuntabilitas individu dalam diskusi kelompok. Berikut ini kelebihan dan kelemahan serta langkah-langkah 
pembelajaran Numbered Head Together Menurut Slavin (Huda, 2016: 203), yaitu sebagai berikut:

Kelebihan Numbered Head Together (NHT):

- Melatih peserta didik untuk dapat bekerja sama dan menghargai pendapat orang lain,

- Melatih peserta didik untuk bisa menjadi tutor sebaya,

- Memupuk sikap kebersamaan,

- Membuat peserta didik menjadi terbiasa dengan perbedaan.

Kelemahan Numbered Head Together (NHT):

- Peserta didik yang sudah terbiasa dengan cara konvensional akan sedikit kewalahan,

- Guru harus bisa memfasilitasi peserta didik,

- Tidak semua peserta didik mendapat giliran.

Sintaks atau langkah-langkah pembelajaran model Kooperatif tipe Numbered Head Together (NHT) terdiri dari enam langkah, yaitu:

Langkah 1. Persiapan

Dalam tahap ini guru mempersiapkan rancangan pelajaran dengan membuat Skenario Pembelajaran (SP), Lembar Kerja Peserta didik (LKS) yang sesuai dengan model pembelajaran kooperatif tipe NHT.

Langkah 2. Pembentukan kelompok
Dalam pembentukan kelompok disesuaikan dengan model pembelajaran kooperatif tipe NHT. Guru membagi peserta didik menjadi beberapa kelompok yang beranggotakan 3-5 orang peserta didik. Guru memberi nomor kepada setiap peserta didik di dalam kelompok sehingga setiap peserta didik dalam tim mempunyai nomor yang berbeda-beda, sesuai dengan jumlah peserta didik di dalam kelompok. Kelompok yang dibentuk merupakan percampuran yang ditinjau dari latar belakang sosial, ras, suku, jenis kelamin dan kemampuan belajar. Selain itu, dalam pembentukan kelompok digunakan nilai tes awal (pretest) sebagai dasar dalam menentukan masing-masing kelompok. Penomoran merupakan hal yang utama di dalam model pembelajaran kooperatif tipe $N H T$.

Langkah 3. Tiap kelompok harus memiliki buku paket atau buku panduan

dalam pembentukan kelompok, tiap kelompok harus memiliki buku paket atau buku panduan agar memudahkan peserta didik dalam menyelesaikan LKS atau masalah yang diberikan oleh guru.

Langkah 4. Diskusi masalah

Dalam kerja kelompok, guru membagikan LKS kepada setiap peserta didik sebagai bahan yang akan dipelajari. Dalam kerja kelompok, setiap 
peserta didik berpikir bersama untuk menggambarkan dan meyakinkan bahwa tiap orang mengetahui jawaban dari pertanyaan yang telah ada dalam LKS atau pertanyaan yang telah diberikan oleh guru. Pertanyaan dapat bervariasi, dari yang bersifat spesifik sampai yang bersifat umum.

Langkah 5. Memanggil nomor anggota atau pemberian jawaban

Dalam tahap ini, guru menyebut satu nomor dan para peserta didik dari tiap kelompok dengan nomor yang sama mengangkat tangan dan menyiapkan jawaban kepada peserta didik di kelas.

Langkah 6. Memberi kesimpulan

Guru Bersama peserta didik menyimpulkan jawaban akhir dari semua pertanyaan yang berhubungan dengan materi yang disajikan.

Model

pembelajaran

Kooperatif tipe Numbered Head Together di dalam penelitian ini pada hakikatnya hampir sama dengan diskusi kelompok, yang membedakannya adalah pemberian nomor yang berbeda kepada tiap anggota kelompok sebagai dasar untuk pemberian tugas yang berbeda sesuai dengan tujuan yang diharapkan melalui tahapan-tahapan

pelaksanaan

Numbered Head Together. Selain itu, pada proses pembelajarannya dibantu dengan Blog sebagai media dan sumber belajar.

\section{Pemahaman Konsep}

Menurut Dahar (Suhartini, 2015: 37) Penguasaan atau pemahaman konsep merupakan kemampuan peserta didik dalam memahami konsep-konsep setelah kegiatan pembelajaran. Pemahaman konsep dapat diartikan sebagai kemampuan peserta didik dalam memahami makna secara ilmiah, baik konsep secara teori maupun penerapannya dalam kehidupan sehari-hari. Keberhasilan suatu program pengajaran diukur berdasarkan perbedaan tingkat berpikir sebelum dan sesudah memperoleh pengalaman belajar.

Menurut Dewi (2018: 32) Pemahaman konsep merupakan kemampuan yang harus dimiliki peserta didik dalam memahami konsep dengan mengetahui dan mengingat sesuatu yang pernah dipelajari atau dialami serta dengan melibatkan kemampuan berfikir berdasarkan pengetahuan yang sudah ada. Konsep dapat berubah-ubah sesuai dengan perkembangan pengetahuan peserta didik tersebut, karena pada dasarnya konsep melibatkan interaksi peserta didik dengan lingkungan sekitarnya. Akan tetapi, keberhasilan belajar bukan hanya bergantung pada lingkungan dan kondisi belajar tetapi juga pada pengetahuan awal peserta didik.

Terdapat empat sifat atau kualitas penting yang dapat diterapkan pada semua konsep yaitu tingkat abstraksi, kompleksitas, differensiasi, dan sentralisasi dari dimensi-dimensi. Adapun kegunaan konsep bagi kehidupan manusia menurut Fraenkel (Supardan, 2015: 54), diantaranya:

- Untuk melakukan efisiensi dan efektivitas bagi manusia

- Adanya klasifikasi atas beberapa individu, 
karakteristik yang serupa kemudian diidentifikasi dan dicari perbedaannya.

- Mereduksi keperluan yang sering dikatakan berulangulang terhadap suatu kajian yang serupa dan sudah diketahui.

- Memudahkan memecahkan masalah

- Menjelaskan sesuatu yang dianggap rumit ataupun memerlukan keterangan yang cukup panjang dan rinci

- Mengonseptualisasi sesuatu secara cermat melalui simbolsimbol.

- Mata rantai penghubung ataupun katalisator antardisiplin ilmu.

Terdapat dua cara untuk memperoleh konsep-konsep yaitu melalui pembentukan konsep dan asimilasi konsep. Pembentukan konsep merupakan proses induktif. Di dalam proses induktif peserta didik dilibatkan belajar penemuan. Dengan melalui belajar penemuan, peserta didik akan merasakan suatu yang dipelajarinya akan bertahan lebih lama dibandingkan dengan cara belajar hapalan. Sementara perolehan konsep melalui asimilasi erat kaitannya dengan proses deduktif. Dalam proses ini peserta didik memperoleh konsep dengan cara menghubungkan atribut konsep yang sudah dikenalnya dengan gagasan yang relevan yang sudah dalam struktur kognitifnya.

Pemahaman konsep dalam penelitian ini adalah kemampuan peserta didik dalam memahami konsep atau mampu mengungkapkan kembali dalam bentuk lain atau dengan katakata sendiri sesuai dengan pengetahuan yang dimilikinya sehingga mudah dimengerti makna dari bahan yang dipelajari tanpa mengubah arti yang ada di dalamnya. Dengan pemahaman terhadap teori atau konsep, peserta didik mampu membedakan, menduga, menjelaskan maupun menarik kesimpulan pada materi usaha mempertahankan kemerdekaan Indonesia.

\section{Usaha Mempertahankan} Kemerdekaan Indonesia

Setelah Jepang menyerah kepada Sekutu, seluruh negara jajahan Jepang di Asia Tenggara termasuk Indonesia diambil alih oleh pasukan Sekutu yaitu AFNEI (Allied Forces Netherlands East Indies). Tugas AFNEI adalah menerima penyerahan kekuasaan dari tangan Jepang, membebaskan tentara Sekutu yang ditahan Jepang, melucuti serta mengumpulkan orang-orang Jepang untuk dipulangkan ke negerinya. Akan tetapi, ketika $A F N E I$ dalam perjalanan untuk menerima penyerahan kekuasaan Indonesia dari tangan Jepang Indonesia memproklamasikan diri sebagai negara merdeka.

Kedatangan tentara Sekutu ternyata juga disertai dengan kedatangan NICA (Netherland Indies Civil Administration) yang bertujuan ingin kembali menegakkan kekuasaan Belanda di Indonesia. Tentara AFNEI bersama NICA sampai ke Indonesia pertama kali pada tanggal 16 September 1945 di Tanjung Priok. Kemudian, Indonesia melakukan berbagai upaya untuk mempertahankan kemerdekaan melalui perjuangan diplomasi dan perjuangan bersenjata. 


\section{METODE PENELITIAN}

Penelitian dilakukan dengan menggunakan metode penelitian eksperimen dengan bentuk kuasi eksperimental karena penelitian yang dilakukan tidak secara penuh atau murni, tetapi dikurangi atau ditampilkan sebagian saja. Bentuk desain eksperimen yang digunakan adalah pretest-posttest control group design. Penelitian dilaksanakan di SMK Darussalam Tarogong Kaler Garut kelas X tahun ajaran 2019/2020.

Instrumen penelitian yang digunakan dalam pengumpulan data yaitu lembar tes tertulis dan kuesioner. Teknik pengumpulan data dilakukan dengan cara tes tulis dan pengisian angket. Lokasi penelitian di SMK Darussalam Tarogong Kaler yang terdapat di KP. Cilame Desa Sukajadi Kecamatan Tarogong Kaler Kabupaten Garut. Perserta didik yang sekolah di sana merupakan orang-orang yang tempat tinggalnya berada di sekitar SMK Darussalam. Sebagian besar peserta didik termasuk masyarakat kelas menengah ke bawah yang masih kurang paham akan arti pentingnya dari pendidikan. Mereka kurang begitu mempedulikan dengan hasil belajar yang mereka dapatkan. Motivasi belajar mereka tergolong rendah.

\section{HASIL DAN PEMBAHASAN}

\section{Hasil}

Dari hasil tes awal sebelum pembelajaran menggunakan blog mobile dan pembelajaran kooperatif tipe Numbered Head Together, diperoleh Skor minimal 0 dan skor maksimal 50 dengan rata-rata nilai 22 . Dari hasil tes akhir setelah dilaksanakan pembelajaran dengan menggunakan blog mobile dan pembelajaran kooperatif tipe Numbered Head Together, diperoleh Skor minimal 10 dan skor maksimal 80 dengan rata-rata nilai 46. Untuk mengetahui apakah terdapat peningkatan pemahaman konsep peserta didik tentang usaha mempertahankan kemerdekaan Indonesia setelah menggunakan blog Mobile dan pembelajaran kooperatif tipe Numbered Head together, maka dilakukan uji gain dengan hasil yang diperoleh rata-rata $\mathrm{N}$ - Gain nya yaitu sebesar 0,29 termasuk kategori rendah.

\section{Pembahasan}

Pemahaman konsep menurut Dewi (2018: 32) adalah "kemampuan yang harus dimiliki peserta didik dalam memahami konsep dengan mengetahui dan mengingat sesuatu yang pernah dipelajari atau dialami serta dengan melibatkan kemampuan berfikir berdasarkan pengetahuan yang sudah ada."

Data hasil penelitian menunjukkan terdapat peningkatan rata-rata nilai yang diperoleh peserta didik setelah dilakukan pembelajaran dengan menggunakan blog mobile dan pembelajaran kooperatif tipe Numbered Head Together. Hal ini menunjukkan bahwa pengetahuan awal peserta didik sangat berperan penting dalam keberhasilan belajar, karena pengetahuan awal ini merupakan dasar dari kemampuan berfikir peserta didik untuk dapat memahami konsep dengan mengetahui dan mengingat sesuatu yang pernah dipelajari atau dialami peserta didik sesuai dengan pendapatnya Dewi (2018) dan Kuntowijoyo (2013). 
Hal tersebut membuktikan bahwa penggunaan media dan model pembelajaran sangat berperan penting dalam membantu guru menjelaskan bahan pengajaran. Media pengajaran sebagai salah satu komponen dalam metode mengajar merupakan salah satu upaya untuk meningkatkan proses interaksi antara guru dan peserta didik serta interaksi antara peserta didik dengan lingkungan belajarnya. Media pengajaran berfungsi sebagai alat bantu mengajar, yakni menunjang penggunaan metode mengajar untuk memudahkan peserta didik dalam memahami apa yang disampaikan oleh guru.

Penjelasan ini sesuai dengan pendapatnya Maswan dan Muslimin (2017:123) mengenai peran atau fungsi pokok dari media pembelajaran itu sendiri, yaitu:
a. Sebagai alat bantu mewujudkan situasi pembelajaran yang efektif dan efisien.
b. Sebagai sarana untuk menumbuhkan dan mengembangkan situasi menarik dan dinamis. belajar mengajar lebih
c. Sebagai bagian integral dalam bentuk sarana untuk memperjelas isi materi pelajaran agar tujuan yang diinginkan tercapai.
d. Sebagai penguat daya tarik atau perhatian peserta didik untuk menangkap pesan- pesan pembelajaran yang ditunjukkan dalam bentuk yang nyata.
e. Sebagai alat untuk memotivasi peserta didik

dalam mempercepat penangkapan konsep dalam proses pembelajaran.

f. Sebagai sarana untuk membantu peserta didik dalam penerimaan dan daya ingat yang lebih lama mengenai materi yang diterimanya.

Blog mobile sendiri sebagai salah satu inovasi dari ilmu pengetahuan dan teknologi yang maju menjadi salah satu faktor penunjang untuk mencapai tujuan pembelajaran. Penggunaan blog juga selain dapat digunakan sebagai media pembelajaran, juga dapat digunakan sebagai sumber belajar. Peserta didik dapat mengakses materi pembelajaran kapan saja dan dimana saja tanpa harus bergantung pada guru serta terikat ruang dan waktu dengan menggunakan smartphone. Selain dapat mengatasi sumber belajar yang terbatas, penggunaan blog mobile ini juga dapat membantu peserta didik melaksanakan proses pembelajaran secara menyenangkan dengan suasana pembelajaran yang tidak monoton. Hal ini sesuai dengan pendapat Sartono (2016: 124) mengenai manfaat blog bagi dunia pendidikan, yaitu sebagai berikut:

- Sebagai rumah belajar dan berbagi guru,

- Meringankan tugas dan beban guru dalam mengajar,

- Meningkatkan minat belajar peserta didik,

- Dapat diakses oleh siapapun di belahan dunia,

- Media silaturahmi. 
Selain penggunaan media pembelajaran, penggunaan model pembelajaran juga menjadi salah satu faktor yang menentukan keberhasilan proses pembelajaran sehingga tujuan pembelajaran dapat tercapai. Model pembelajaran dapat dijadikan pola pilihan dalam rangka mencapai tujuan Pendidikan, menurut Joyce \& Weil (Rusman, 2016: 132) 'Model pembelajaran merupakan suatu rencana atau pola yang dapat digunakan untuk membentuk kurikulum (rencana pembelajaran jangka panjang), merancang bahan pembelajaran, dan membimbing pembelajaran di kelas atau yang lain.' Terdapat

beberapa kemungkinan yang menyebabkan kurang optimalnya peningkatan pemahaman konsep peserta didik tentang usaha mempertahankan kemerdekaan Indonesia setelah menggunakan blog mobile dan pembelajaran kooperatif tipe Numbered Head Together. Diantaranya yaitu pemilihan media pembelajaran yang kurang tepat. Menurut Sudjana dkk (2017: 4) terdapat beberapa kriteria dalam memilih media pengajaran, diantaranya:

1. Ketepatannya dengan tujuan pengajaran,

2. Dukungan terhadap isi bahan pelajaran,

3. Kemudahan dalam memperoleh media,

4. Keterampilan guru dalam menggunakannya,

5. Tersedia waktu untuk menggunakannya
6. Sesuai dengan taraf berpikir peserta didik.

Berdasarkan kriteria di atas, dapat diketahui bahwa tidak semua media pembelajaran tepat digunakan untuk membantu guru dalam menjelaskan bahan pengajaran. Sebaliknya, Penggunaan media yang kurang tepat dapat mempersulit guru menjalankan tugasnya. Oleh karena itu, media pembelajaran bukan merupakan suatu keharusan melainkan sebagai pelengkap jika dianggap perlu untuk mempertinggi kualitas belajar dan mengajar.

Selain pemilihan media pembelajaran yang kurang tepat, cara pembentukan untuk memperoleh konsep tentang usaha mempertahankan kemerdekaan Indonesia dapat dianggap masih kurang efektif. Menurut Fraenkel (Supardan, 2015: 54)

Terdapat dua cara untuk memperoleh konsep-konsep yaitu melalui pembentukan konsep dan asimilasi konsep. Pembentukan konsep merupakan proses induktif. Di dalam proses induktif peserta didik dilibatkan belajar penemuan. Dengan melalui belajar penemuan, peserta didik akan merasakan suatu yang dipelajarinya akan bertahan lebih lama dibandingkan dengan cara belajar hapalan. Sementara perolehan konsep melalui asimilasi erat kaitannya dengan proses deduktif. Dalam proses ini peserta didik memperoleh konsep dengan cara menghubungkan atribut konsep 
yang sudah dikenalnya dengan gagasan yang relevan yang sudah dalam struktur kognitifnya.

\section{Berdasarkan pernyataan dari} Fraenkel tersebut, dapat dikatakan bahwa faktor lain yang menyebabkan sebagian besar peserta didik pada kelas eksperimen belum tuntas belajar adalah proses pembelajaran yang berlangsung secara deduktif atau dilakukan dengan cara asimilasi konsep. Peserta didik memperoleh konsep dengan cara menghubungkan atribut konsep yang sudah dikenalnya dengan gagasan yang relevan yang sudah ada dalam struktur kognitifnya. Sehingga konsep yang diterimanya bersifat sebentar.

Pernyataan Fraenkel ini didukung dengan Teori belajar Kognitif. Menurut Teori Belajar Kognitif (Mudlofir dan Rushdiyah, 2016: 1), "belajar merupakan aktivitas yang melibatkan proses berpikir yang sangat kompleks." Berdasarkan teori tersebut tingkah laku seseorang ditentukan oleh persepsi serta pemahamannya tentang situasi yang berhubungan dengan tujuan belajarnya. Penggunaan model pembelajaran juga dapat menjadi salah satu faktor penyebab hasil belajar yang diperoleh kurang optimal. Hal tersebut dikarenakan, tidak semua model pembelajaran cocok dengan semua mata pelajaran. Setiap mata pelajaran memiliki beberapa materi dengan tingkat keluasan dan kedalaman yang berbeda-beda. Oleh karena itu, terdapat beberapa kriteria dalam memilih model pembelajaran sehingga pembelajaran efektif dan efisien, diantaranya yaitu hasil yang diharapkan, materi apa yang harus dipahami dan bagaimana proses pembelajaran yang harus dilakukan seperti yang dikatakan oleh Priansa (2017: 188).

Pemaparan di atas juga membuktikan kebenaran dari pendapat Edgar Dale (Abdulhak dan Darmawan, 2013: 113) tentang teori cone of experience yang menyatakan bahwa 'Simbol dan gagasan yang abstrak dapat lebih mudah dipahami dan diserap manakala diberikan dalam bentuk pengalaman yang konkret'. Pemikiran Edgar Dale tentang kerucut pengalaman (Cone of Experience) menunjukkan bahwa semakin konkrit pembelajaran yang dilakukan oleh seseorang, maka hasil belajarnya juga akan optimal. Dengan kata lain, pembelajaran dengan menggunakan blog mobile dan pembelajaran kooperatif tipe Numbered Head Together ini belum termasuk konkrit, sehingga hasil belajar yang diperoleh kurang optimal.

\section{SIMPULAN DAN SARAN}

\section{A. SIMPULAN}

Penggunaan blog mobile dan pembelajaran kooperatif tipe Numbered Head Together dalam pembelajaran sejarah, selain dapat meningkatkan aktivitas belajar, menumbuhkan dan mengembangkan situasi belajar yang menarik dan dinamis serta membantu peserta didik dalam memahami materi yang diberikan oleh guru, juga dapat, membuat peserta didik termotivasi dan terbantu dalam menerima dan memahami materi. Penggunaan blog mobile dan pembelajaran kooperatif tipe Numbered Head Together mengembangkan nilai akademik dan sikap sosial peserta didik dan 
berpengaruh positif terhadap pembelajaran sejarah.

Pembelajaran yang dilakukan tanpa perencanaan yang baik dan didukung dengan media pembelajaran dan penggunaan model pembelajaran yang tepat membuat hasil pembelajaran yang didapatkan kurang optimal. Berdasarkan hasil temuan dalam penelitian, analisis data, serta pembahasan pada bab sebelumnya maka dapat disimpulkan bahwa Penggunaan blog mobile dan pembelajaran kooperatif tipe Numbered Head Together dapat meningkatkan pemahaman konsep peserta didik tentang usaha mempertahankan kemerdekaan Indonesia.

\section{SARAN}

Berdasarkan hasil penelitian dan kesimpulan, peneliti memberikan saran supaya dalam melakukan suatu kegiatan pembelajaran dalam rangka mencapai tujuan, selain mempertimbangankan kelebihan dan kekurangan juga harus direncanakan terlebih dahulu secara seksama supaya tujuan dari kegiatan pembelajaran dapat tercapai secara optimal sesuai dengan yang diharapkan.

\section{DAFTAR PUSTAKA \\ Buku}

Abdulhak dan Darmawan, I. 2013. Teknologi Pendidikan. Bandung: PT Remaja Rosdakarya.

Creswell, J. W. 2018. Research Design: Pendekatan Metode Kualitatif, Kuantitatif dan Campuran. Yogyakarta: Pustaka Pelajar.
Darmawan, D. 2016. Pengembangan E-Learning: Teori dan Desain. Bandung: PT Remaja Rosdakarya.

Huda, M. 2016. Model-Model Pengajaran dan Pembelajaran: Isu-Isu Metodis dan Paradigmatis. Yogyakarta: Pustaka Pelajar.

Kuntowijoyo. 2013. Pengantar Ilmu Sejarah. Yogyakarta: Tiara Wacana.

Maswan dan Muslimin, K. 2017. Teknologi Pendidikan: Penerapan Pembelajaran yang Sistematis. Yogyakarta: Pustaka Pelajar.

Mudlofir dan Evi F. R, A. 2016. Desain Pembelajaran Inovatif: Dari Teori ke Praktik. Jakarta: PT Raja Grafindo Persada.

Priansa, D. J. 2017. Penerapan Strategi dan Model Pembelajaran. Bandung: CV. Pustaka Setia.

Rusman, 2016. Model-Model Pembelajaran: Mengembangkan

Profesionalisme Guru. Jakarta: PT Raja Grafindo Persada.

Sanjaya, W. 2011. Kurikulum dan Pembelajaran: Teori dan Praktik Penerapan Kurikulum Tingkat Satuan Pendidikan (KTSP). Jakarta: Kencana.

Sanjaya, W. 2014. Strategi Pembelajaran Berorientasi 
Standar Proses Pendidikan. Jakarta: Kencana.

Sanjaya, W. 2017. Perencanaan dan Desain Sistem Pembelajaran. Jakarta: Kencana.

Sapriya. 2017. Pendidikan IPS: Konsep dan Pembelajaran. Bandung: PT Remaja Rosdakarya.

Sardiman dan Lestariningsih. 2017. Sejarah Indonesia. Jakarta: Kementerian Pendidikan dan Kebudayaan.

Sawitri, I. 2016. Buku Guru Sejarah Indonesia Untuk SMA/MA/SMK Kelas X (Wajib). Surakarta: Mediatama.

Slavin, R. E. 2016. Cooperative Learning: Teori, Riset dan Praktik. Bandung: Nusa Media.

Solihatin dan Raharjo, E. 2012. Cooperative Learning: Analisis Model Pembelajaran IPS. Jakarta: Bumi Aksara.

Sudjana dan Rivai, N. 2017. Media Pengajaran (Penggunaan dan Pembuatannya). Bandung: Sinar Baru Algensindo.

Sugiyono. 2017. Metode Penelitian Pendidikan: Pendekatan Kuantitatif, Kualitatif, dan $R \& D$. Bandung: Alfabeta.

Sundayana, R. 2012. Komputasi Data Statistika: Pengolahan dan Analisis Data Berbantuan MS.
Excel dan SPSS. Garut: SKIP Garut Press.

Sundayana, R. 2015. Statistika Penelitian Pendidikan. Bandung: Alfabeta.

Supardan, D. 2015: Pengantar Ilmu Sosial: Sebuah Kajian Pendekatan Struktural. Jakarta: PT Bumi Aksara.

Suprijono, A. 2016. Cooperative Learning: Teori dan Aplikasi PAIKEM. Yogyakarta: Pustaka Pelajar.

Surya, 2015. Psikologi Guru: Konsep dan Aplikasi Dari Guru, Untuk Guru. Bandung: Alfabeta.

Suyono dan Hariyanto. 2016. Belajar dan Pembelajaran: Teori dan Konsep Dasar. Bandung: PT Remaja Rosdakarya.

Thobroni, M. 2016. Belajar dan Pembelajaran: Teori dan Praktik. Yogyakarta: Ar-Ruzz Media.

Tn. 2019. Pedoman Penulisan Proposal Penelitian Tesis. Garut: Sekolah Pasca Sarjana Institut Pendidikan Indonesia (IPI).

Undang-Undang Republik Indonesia No. 20 tahun 2003.

\section{Jurnal}

Darmawan, D. 2017. Web Streaming TVUPI as Modern Communication Model and 
Contribution To Learning Quality. Mimbar. 33(1). 198207.

Darmawan, D., Kartawinata, H. dan Astorina, W. (2018). "Development of Web-Based Electronic Learning System (WELS) in Improving the Effectiveness of the Study at Vocational High School Dharma Nusantara". Journal of Computer Science. 14(4), 562-573.

Daud dan Fauzan, F. (2011). "Penerapan Model Pembelajaran Kooperatif Tipe Numbered Head Together Untuk Meningkatkan Aktivitas dan Hasil Belajar Pada Konsep Ekosistem Bagi Peserta didik Kelas VII.A SMPN 5 Takalar". Jurnal Chemica. 12 (1), 40-48.

Kristiyanti, M. (2011). Blog Sebagai Alternatif Media Pembelajaran. Majalah Ilmiah Informatika. 2 (2). 33-45.

Sartono. (2016). "Pemanfaatan Blog Sebagai Media Pembelajaran Alternatif di Sekolah". Transformatika. 12 (1). 120- 134.

Shavab dan Gurdjita. (2017). "Pemanfaatan Blog Sebagai Media Pembelajaran Dalam Meningkatkan Keterampilan Berpikir Kritis Calon Guru Sejarah". Jurnal Candrasangkala. 3 (1). 10-19.

\section{Tesis}

Abdillah, Joyoatmojo dan Noviani. 2017. Pemanfaatan Blog
Sebagai Media Pembelajaran Dalam Meningkatkan Prestasi Belajar Peserta didik. Tesis Magister Pada Program Studi Pendidikan Ekonomi Universitas Sebelas Maret. Tidak diterbitkan. (online). Terdapat di: https://jurnal.uns.ac.id/bise/articl e/download/16814/13572. (1 Mei 2019)

Dewi, Y. 2018. Penerapan Multimedia Interaktif Model Simulasi Pada Pembelajaran Kontekstual Untuk Meningkatkan Penguasaan Konsep dan Motivasi Belajar Peserta didik Kelas V: Penelitian Pre Eksperimen di SDN Cimuncang 1 Garut Tahun Ajaran 2018/2019 Pada Mata Pelajaran IPA dengan Pokok Bahasan Sistem Pernapasan Manusia. Tesis Magister Pada Program Studi Tekpend IPI Garut: Tidak diterbitkan.

Suhartini, N. 2015. Penerapan Multimedia Interaktif Dalam Meningkatkan Penguasaan Konsep Dan Keterampilan Proses Belajar Peserta didik Pada Pembelajaran Akuntansi: Penelitian Quasi Experiment di Kelas XI IPS MAN 1 Garut Tahun Pelajaran 2014/2015. Tesis Magister Pada Program Studi Tekpend STKIP Garut: Tidak diterbitkan.

\section{Internet}

Ibeng, Parta. 2019. AFNEI:

Pengertian, Sejarah, Tugas, Tujuan Ke Indonesia. Online. 
N. Dewi Ratnaningsih ${ }^{1}$, Jamilah ${ }^{2}$,Endang Dimyati ${ }^{3}$ / Penggunaan Blog dan Pembelajaran Kooperatif Tipe Numbered Head Together untuk Meningkatkan Pemahaman Konsep Tentang Usaha Mempertahankan Kemerdekaan Indonesia

Terdapat di:

https://pendidikan.co.id/afnei-

pengertian-sejarah-tugas-

tujuan-ke-indonesia/. (23

Agustus 2019). 
N. Dewi Ratnaningsih ${ }^{1}$, Jamilah ${ }^{2}$, Endang Dimyati ${ }^{3} /$ Penggunaan Blog dan Pembelajaran Kooperatif Tipe Numbered Head Together untuk Meningkatkan Pemahaman Konsep Tentang Usaha Mempertahankan

Kemerdekaan Indonesia 